\title{
Human Platelets and Factor XI
}

\section{LOCALIZATION IN PLATELET MEMBRANES OF}

\author{
FACTOR XI-LIKE ACTIVITY AND ITS \\ FUNCTIONAL DISTINCTION FROM PLASMA FACTOR XI
}

\author{
Myatt S. Lipscomb and Peter N. Walsh, Specialized Center on Thrombosis \\ Research and Department of Medicine, Temple University School of Medicine, \\ Philadelphia, Pennsylvania 19140
}

\begin{abstract}
A B S T R A C T Because human platelets participate in the contact phase of intrinsic coagulation and contain a Factor XI-like coagulant activity, the nature of the Factor XI-like activity was examined and compared with purified plasma Factor XI. The platelet factor XIlike activity was sedimented with the particulate fraction of a platelet lysate, was inactivated by heat $\left(t_{1 / 2} 3.5\right.$ $\min , 56^{\circ} \mathrm{C}$ ), was not a nonspecific phospholipid activity, and was destroyed by treatment with Triton X-100. Isolated platelet membranes were four-fold enriched in Factor XI activity and similarly enriched in plasma membrane marker enzymes. The Factor XI-like activity of platelet membranes was detected only when assayed in the presence of kaolin, which suggests that it is present in an unactivated form and can participate in contact activation. Concanavalin A inhibited the Factor XI-like activity of platelet lysates and platelet membranes but not of plasma or purified Factor XI. A platelet membrane-Factor XI complex was isolated after incubation of membranes with purified Factor XI. The Factor XI activity of the platelet membrane-plasma Factor XI complex was inhibited by concanavalin A, whereas unbound plasma Factor XI retained activity. An antibody raised against plasma Factor XI inhibited the in vitro Factor XI activity of plasma and of the platelet membrane-plasma Factor XI complex but had no effect on
\end{abstract}

Portions of this work were previously published in abstract form in 1975. Thromb. Diath. Hemorrh. 34: 919, and in 1977. Fed. Proc. 36: 351 .

Dr. Lipscomb was the recipient of a fellowship (HL05976) from the National Institutes of Health and a subsequent fellowship from the National Hemophilia Foundation. Dr. Walsh is a recipient of a Research Career Development Award (HL70545) from the National Institutes of Health. Address requests for reprints to Dr. Walsh.

Received for publication 18 May 1978 and in revised form 19 January 1979. the endogenous Factor XI-like activity of washed lysed platelets or isolated platelet membranes. Washed platelets and isolated platelet membranes obtained from a Factor XI-deficient donor without a history of excessive bleeding had normal quantities of platelet Factor XIlike activity and normal behavior in the contact phase of coagulation (collagen-induced coagulant activity). These results indicate that platelet membranes contain an endogenous Factor XI-like activity that is functionally distinct from plasma Factor XI.

\section{INTRODUCTION}

Platelets washed free of loosely adsorbed coagulation factors and treated with collagen can initiate intrinsic coagulation (1). Although collagen preparations have been shown to provide a surface for Factor XII activation in plasma $(2,3)$, and platelets have been shown to provide procoagulant phospholipid $(4,5)$, nevertheless, the initiation of coagulation by collagen-treated platelets appears to be independent of Factor XII and distinct from the platelet phospholipid coagulant activity, platelet Factor 3 (1). A Factor XII-like activity has been demonstrated in washed platelets from normal blood which substitutes for plasma Factor XI in clotting assays (6). Evidence that platelet Factor XI-like activity had a role in the initiation of intrinsic coagulation by collagen-treated platelets came as a result of studies showing that platelets deficient in Factor XI-like activity had substantially reduced capacity to initiate coagulation in the presence of collagen (1). From these findings, an alternative pathway for initiation of intrinsic coagulation was proposed which apparently operates in the absence of plasma Factor XI and XII provided platelet Factor XI or XI-like activity is present. This pathway or platelet activity has been termed "collagen-induced coagulant activity." 
As collagen is normally present at sites of vascular injury, knowledge of the mechanism of collagen-induced coagulant activity may lead to an understanding of how the process of blood coagulation is triggered in vivo. We have therefore explored the nature and subcellular localization of the platelet Factor XI-like activity and compared it with purified plasma Factor XI. The studies reported here indicate that, although platelet membranes can bind purified plasma Factor XI, the endogenous platelet Factor XI-like activity is functionally distinct from plasma Factor XI.

\section{METHODS}

All chemicals obtained commercially were the best grade available. Materials were obtained from the following sources: $\mathrm{Al}(\mathrm{OH})_{3}$ (Amphogel) from Wyeth Laboratories (Marietta, Pa.); human immunoglobulin (Ig)G and agarose-anti-human IgG from Miles Laboratories, Inc. (Elkhart, Ind.); agarose (Biogel A-15 m 100-200 mesh) from Bio-Rad Laboratories (Richmond, Calif.); kaolin from J. T. Baker Chemical Co. (Phillipsburg, N. J.); thromboplastin and plasma deficient in coagulation Factors II, V, VII, VIII, IX, or XII from Dade Division, American Hospital Supply Corp. (Miami, Fla.); plasma deficient in Factors XI or XII from individuals without detectable (by clotting assay) plasma Factors XI or XII; Freund's complete adjuvant and concanavalin A from Calbiochem (San Diego, Calif.); CM Sepharose (CL-6B), protein A Sepharose (CL-4B), and QAE Sephadex (A-50) from Pharmacia Fine Chemicals (Piscataway, N. J.); bovine albumin (Fraction V from bovine plasma), crystallized bovine serum albumin, heparin, bis-p-nitrophenylphosphate, $p$-nitrophenol, $p$-nitrophenyl acetate, $p$-iodonitrotetrazolium violet grade II, ATP (99-100\%), succinate disodium salt, phenolphthalein glucuronic acid (free acid), $p$-nitrophenylphosphate disodium salt and sucrose (grade 1) from Sigma Chemical Co. (St. Louis, Mo.); agar for immunodiffusion from Difco Laboratories (Detroit, Mich.); 1,2,4 aminonaphthol sulfonic acid from Aldrich Chemical Co. (Milwaukee, Wis.) was recrystallized as described (7); acid-soluble collagen was prepared from bovine tendon (Sigma Chemical) as described elsewhere (8) to a concentration of $1 \mathrm{mg} / \mathrm{ml}$. Brain cephalin was prepared by the method of Folch as described (9).

Preparation of washed platelet suspensions. Blood was collected from human donors as described (6). Platelets were washed by albumin density gradient centrifugation $(6,10)$ and counted by phase contrast microscopy (11) and by using a model ZBI particle counter (Coulter Electronics, Inc., Hialeah, Fla.), and results were averaged.

Factor XI and Factor XI antigen purification. All operations were done at $0-4^{\circ} \mathrm{C}$ in plastic or siliconized glass containers. Frozen plasma ( 2 liters), collected with acid-citratedextrose anticoagulant, was allowed to thaw for $24 \mathrm{~h}$ at $4^{\circ} \mathrm{C}$ in 1 liter of solution containing $30 \mathrm{mM}$ imidazole- $\mathrm{HCl}$ buffer, pH 6.0/3 $\mathrm{mM} \alpha$-toluenesulfonyl flouride/3 $\mathrm{mM}$ benzamidine hydrochloride $/ 3 \mathrm{mM}$ EDTA $/ 150 \mu \mathrm{g} / \mathrm{ml}$ hexadimethrine bromide. The mixture was brought to $\mathrm{pH} 6.0$ by dropwise addition of $5 \mathrm{M}$ acetic acid, centrifuged for $15 \mathrm{~min}$ at $14,000 \mathrm{~g}$, and the treated plasma collected by decantation (plasma fraction).

Factor XI and Factor XI antigen were purified from the plasma fraction by ion exchange and affinity chromatography steps as summarized in Table I. Factor XI preparations contained 240-310 U of Factor XI clotting activity $/ \mathrm{ml}$ when assayed with kaolin and about $15 \mathrm{U}$ of Factor $\mathrm{XI} / \mathrm{ml}$ when assayed without kaolin. The protein was $1.0-1.2 \mathrm{mg} / \mathrm{ml}$ when determined by the method of Lowry et al. (12) or by amino acid analysis. The Factor XI preparations were assessed 87$93 \%$ pure by densitometer scans of $5 \%$ sodium dodecyl sulfate polyacrylamide gels after electrophoresis of nonreduced and reduced samples containing 5,10 , and $20 \mu \mathrm{g}$ of protein. Nonreduced and reduced samples on sodium dodecyl sulfate polyacrylamide gels, respectively, showed major bands at 160,000 and 83,000 daltons. Minor bands had apparent molecular weights of 83,000 in nonreduced samples and 54,000 and 28,000 in reduced samples. Impurities could be fragments of Factor XI, IgG fragments, or both. Prekallikrein activity was not detected in Factor XI preparations. For antigen, two successive preparations were combined, dialyzed exhaustively against water without apparent precipitation, divided into $50-\mu \mathrm{g}$ aliquots, and freeze-dried in vacuo (Factor XI antigen).

Factor XI antibody. Rabbits were immunized with injections of emulsified Factor XI antigen $(50 \mu \mathrm{g})$ in $0.9 \%$ saline, $0.5 \mathrm{ml} /$ Freund's complete adjuvant, $0.5 \mathrm{ml}$. Injections were given at 8- and 10-d intervals. 1 wk after the fourth injection, the sera of two rabbits were positive for Factor XI antibody by immunodiffusion assays (13); anti-IgG was also present. Antisera were treated with $1 / 10$ vol of $\mathrm{Al}(\mathrm{OH})_{3}$ gel $(6.4 \mathrm{mg} / \mathrm{ml}$ final concentration) for $10 \mathrm{~min}$ at room temperature and centrifuged. The adsorbed antisera were heated at $56^{\circ} \mathrm{C}$ for 30 min in glass tubes and centrifuged at $12,000 \mathrm{~g}$ for $30 \mathrm{~min}$ at $4^{\circ} \mathrm{C}$. A pool of treated antisera was purified by precipitation with $1 / 3$ vol of a saturated ammonium sulfate solution. The precipitate was dissolved in $50 \mathrm{mM}$ Tris- $\mathrm{HCl}$ buffer, $\mathrm{pH}$ 7.8-

TABLE I

Purification of Human Factor XI

\begin{tabular}{lcccrr}
\hline \multicolumn{1}{c}{ Fraction } & $\begin{array}{c}\text { Total } \\
\text { protein }\end{array}$ & $\begin{array}{c}\text { Total } \\
\text { coagulation }\end{array}$ & $\begin{array}{c}\text { Specific } \\
\text { coagulation } \\
\text { activity }\end{array}$ & Purification & Yield \\
\hline Plasma & $m g$ & $U$ & $U / m g$ & & $\%$ \\
CM Sepharose & 134,000 & 2,000 & 0.015 & 1 & 100 \\
QAE Sepharose & 100 & 1,100 & 11 & 733 & 55 \\
Protein A Sepharose & 100 & 1,000 & 10 & 667 & 50 \\
Anti-IgG Sepharose & 48 & 1,000 & 21 & 1,400 & 50 \\
Heparin agarose 1 & 11 & 1,000 & 91 & 6,067 & 50 \\
Heparin agarose 2 & 3.0 & 450 & 150 & 10,000 & 23 \\
\hline
\end{tabular}

See Methods for explanation. 
$200 \mathrm{mM} \mathrm{NaCl}-0.02 \% \mathrm{NaN}_{3}$, dialyzed, and applied to a 0.9 $\times 14-\mathrm{cm}$ human IgG-agarose column (equilibrated with dialysis buffer) at a flow rate of $8 \mathrm{ml} / \mathrm{h}$. The unadsorbed IgG fraction containing anti-Factor XI and no anti-IgG was precipitated with 1 vol of saturated ammonium sulfate solution. The precipitate collected by centrifugation was dissolved in $10 \mathrm{ml}$ of $2 \mathrm{mM}$ Tris- $\mathrm{HCl}$ buffer, $\mathrm{pH} 7.8-0.9 \% \mathrm{NaCl}$, and dialyzed $24 \mathrm{~h}$ at $4^{\circ} \mathrm{C}$ against 2-liter changes of the Tris-saline buffer. Rabbit sera collected before immunization were processed like rabbit antisera except adsorption on a human IgG-agarose column was omitted (preimmune rabbit antibody fraction). On double immunodiffusion tests, $3 \mu \mathrm{l}$ of anti-Factor XI antibody showed no positive reaction with $3 \mu$ l of normal pooled plasma (plasma Factor XI concentration too low) or $3 \mu \mathrm{l}$ ( $3 \mu \mathrm{g}$ protein) of pure human IgG. A strong line of precipitation was found in the agar between wells containing $3 \mu$ l of anti-Factor XI antibody and $3 \mu \mathrm{l}$ of purified Factor XI ( $3 \mu \mathrm{g}$ protein) with a specific activity of $150 \mathrm{U} / \mathrm{mg}$ protein. A second line of precipitation was barely discernible. Preimmune rabbit antibody was negative on all double immunodiffusion tests and did not inhibit Factor XI clotting activity in normal pooled plasma. Rabbit Factor XI antibody diluted 1:50 in normal plasma totally inhibited plasma Factor XI clotting activity. When diluted 1:500, inhibition was 50\%. Rabbit Factor XI antibody was also a potent inhibitor of purified plasma Factor XI and trypsin-activated Factor XI (Factor $\mathrm{XI}_{\mathrm{a}}$ ).

Gel immunodiffusion. Gel immunodiffusion was done according to Ouchterlony (13).

Preparation of heparin conjugated to agarose. Agarose was activated with cyanogen bromide according to Porath (14). Heparin was covalently attached to activated agarose (15) exactly as described by Fujikawa et al. (16) and washed exhaustively with $0.1 \mathrm{M}$ Tris- $\mathrm{HCl}$ buffer, $\mathrm{pH} \mathrm{9.0/2} \mathrm{M} \mathrm{NaCl}$. The agarose was qualitatively tested for heparin with toluidine blue.

Preparation of IgG conjugated to agarose. IgG agarose was prepared according to Wilchek et al. (17).

Isolation of platelet plasma membranes. 5 single U (ca $450 \mathrm{ml}$ each) of fresh blood in acid-citrate-dextrose were obtained from a local blood bank (Community Blood and Plasma, Philadelphia, Pa.). Platelet-rich plasma and washed platelets were prepared essentially according to method I of Baenziger and Majerus (18). Platelet yield was generally 70$80 \%$ overall. Platelet membranes enriched in plasma membranes were isolated according to Barber and Jamieson (19). $5 \mathrm{U}$ of platelets yielded $6-10 \mathrm{mg}$ of protein in the plasma membrane fraction. Plasma membrane fractions contained a phospholipid:protein ratio of 1:4.

Protein determination. Protein was measured after precipitation with $10 \%$ trichloroacetic acid by the method of Lowry et al. (12) with bovine serum albumin as the standard. For purified Factor XI (Table I) the method gave the same value as that determined by amino acid analysis with L-norleucine as an internal standard. Amino acid analysis was done on $50-\mu \mathrm{g}$ protein samples hydrolyzed with $6 \mathrm{~N} \mathrm{HCl}$ in sealed, evacuated vials with a Beckman model 119 automatic amino acid analyzer (Beckman Instruments, Inc., Spinco Div., Palo Alto, Calif.) equipped with an Infotronic integrator (Columbia Scientific Industries Corp., Austin, Tex.). For platelet membrane fractions, the trichloroacetic acid precipitates were washed with $5 \%$ trichloroacetic acid, then diethylether:ethanol $(1: 1, \mathrm{vol} / \mathrm{vol})$ as described by Bosmann et al. (20).

Phospholipid analysis. Total lipids were extracted three times with chloroform:methanol $(2: 1, \mathrm{vol} / \mathrm{vol})$ at room temperature for $24 \mathrm{~h}$ and partitioned against $\mathrm{NaCl}$ by the method of Folch et al. (21). Phosphorus, determined after perchloric acid combustion (22), was analyzed by the method of Bartlett
(23) with crystalline $\mathrm{KH}_{2} \mathrm{PO}_{4}$ as a standard. Phosphorus was calculated as described elsewhere (24) according to Bosmann et al. (20).

Enzyme assays. The $\mathrm{Mg}^{2+}-\mathrm{Ca}^{2+}$-dependent ATPase (EC 3.6.1.3) was measured according to the method of Chambers et al. (25). The $\mathrm{Na}^{+} \mathrm{K}^{+}$ATPase (EC 3.6.1.4) was measured by the method of Wallach and Kamat (26). Phosphodiesterase (ED 3.1.4.1) was measured by the method of Koerner and Sinsheimer (27). Alkaline and acid phosphatases (phosphomonoesterases) (EC 3.1.3.1 and EC 3.1.3.2) were measured by the release of $p$-nitrophenol solution as standard (28). $N$-Acetyl- $\beta$-glucosaminidase (EC 3.2.1.30) was determined by the method of Langley and Jevons (29) as modified by Barber and Jamieson (19). $\beta$-Glucuronidase (EC 3.2.1.31) was measured with phenolphthalein glucuronic acid as substrate (30). Esterase activity (EC 3.1.1.1) was determined as described by Bier (31) with $p$-nitrophenol acetate as substrate. Succinate dehydrogenase was measured according to Pennington (32) as $\boldsymbol{p}$-iodonitrotetrazolium violet reductase. Lactate dehydrogenase was measured according to Sigma Chemical Co. technical bulletin 340-UV. All enzyme assays were linear with respect to time and enzyme concentration.

Coagulation assays. Factor VIII, IX, XI, and XII clotting activities were measured by a kaolin-activated partial thromboplastin time with the appropriate factor-deficient substrate plasma. Samples to be tested were diluted into $50 \mathrm{mM}$ imidazole- $\mathrm{HCl}$ buffer, $\mathrm{pH} 7.3-100 \mathrm{mM} \mathrm{NaCl}$. Substrate plasma, $0.1 \mathrm{ml}$, was incubated for $10 \mathrm{~min}$ at $37^{\circ} \mathrm{C}$ in $10 \times 75-\mathrm{mm}$ clear plastic tubes containing $0.1 \mathrm{ml}$ of appropriately diluted sample and $0.05 \mathrm{ml}$ of a suspension containing $50 \mathrm{mM}$ imidazole- $\mathrm{HCl}$ buffer, pH 7.3-100 mM NaCl-kaolin $(5 \mathrm{mg} / \mathrm{ml}) / 0.25 \mathrm{mg}$ brain cephalin (9). The mixture was recalcified with $0.05 \mathrm{ml}$ of 50 $\mathrm{mM} \mathrm{CaCl}{ }_{2}$ (prewarmed) and mixed, and the clotting time measured at $37^{\circ} \mathrm{C}$. The observed clotting times were converted to clotting units by comparison with clotting times of dilutions of pooled normal plasma standard from five normal donors which was defined as having $1 \mathrm{U} / \mathrm{ml}$ of each coagulation factor. A linear relation on log-log paper existed between dilution of sample and clotting time from 0.4 to $0.0005 \mathrm{U} / \mathrm{ml}$. To measure activated coagulation factors, kaolin (see above) was omitted from the assay mixture.

Factor II, V, VII, and X clotting activities were measured by thromboplastin-activated one-stage prothrombin time with the appropriate factor-deficient substrate plasma. Samples to be tested were diluted (see above). Substrate plasma, $0.1 \mathrm{ml}$, was incubated for $2 \mathrm{~min}$ at $37^{\circ} \mathrm{C}$ in $10 \times 75-\mathrm{mm}$ glass tubes containing $0.1 \mathrm{ml}$ of appropriately diluted sample. Warm thromboplastin $(0.2 \mathrm{ml})$ was added and mixed, and the clotting time measured at $37^{\circ} \mathrm{C}$. Data were plotted and activity (units) determined as stated above. A linear relation on log-log paper existed between dilution of sample and clotting time from 0.5 to about $0.002 \mathrm{U} / \mathrm{ml}$. Collagen-induced coagulant activity of washed platelets was assayed as previously described (33).

\section{RESULTS}

Elution of coagulation factor activities from platelets. To examine the elution of coagulation factor activities from platelets separated up to six times by albumin density gradient centrifugation, platelet suspensions centrifuged $1,2,3,4,5$, and 6 times were assayed on 8-22 separate occasions for each of the following factors: II, V, VII, VIII, IX, X, XI, and XII. Factor II, VII, IX, and X activities were not detected 
in platelet suspensions after two separations. For removal of detectable Factor VIII activity, four or five separations were required. In about half the experiments, Factor XII activity was absent from platelets after three separations, whereas trace amounts of Factor XII activity remained after three to six separations in the remainder. Unlike the above factor activities, Factor V and XI activities were consistently present in platelet suspensions separated up to six times. Factor $\mathrm{V}$ and $\mathrm{XI}$ activities in washed platelet suspensions were increased by a factor of about four in lysed platelets.

Platelet Factor XI-like activity in washed platelets and platelet lysates. Platelets were separated twice by albumin density gradient centrifugation, centrifuged at $1,000 \mathrm{~g}$, resuspended in $1 / 10 \mathrm{vol}$ calcium-free Tyrode's solution, $\mathrm{pH} 6.5 / 1 \mathrm{mM}$ EDTA, and diluted with $9 / 10 \mathrm{vol}$ calcium-free Tyrode's, $\mathrm{pH}$ 7.3. The 7.2 $\times 10^{8}$ platelets in $8 \mathrm{ml}$ were lysed by freezing and thawing, and the sample assayed for Factor XI and Factor V. The platelet lysate containing $3 \mathrm{U}$ Factor XI and $19 \mathrm{U}$ Factor $\mathrm{V}$ activity per $10^{11}$ platelets was centrifuged at $100,000 \mathrm{~g}$ for $60 \mathrm{~min}$, and the supernate and resuspended sediment were assayed for Factor XI and $\mathrm{V}$ activity, $93 \%$ of the Factor XI-like activity and $62 \%$ of the Factor $\mathrm{V}$ sedimented with the particulate fraction. Triton X-100 (0.5\% final concentration; Rohm and Haas Co., Philadelphia, Pa.) abolished the Factor XI-like activity of the particulate fraction, whereas $70 \%$ of the sedimented Factor $\mathrm{V}$ was solubilized. In control experiments, Triton X-100 had no effect on the Factor XI activity of normal plasma. In heat stability studies, insoluble platelet Factor XI-like activity had an initial $\mathrm{t}_{1 / 2}$ of $3.5 \mathrm{~min}$ at $56^{\circ} \mathrm{C}$.

Localization of platelet Factor XI activity in platelet plasma membranes. A glycerol lysate (19) of $10 \mathrm{U}$ of platelets $\left(6 \times 10^{11}\right.$ platelets) contained $50 \mathrm{U}$ of Factor XI activity with a specific activity of 0.046 Factor XI $\mathrm{U} / \mathrm{mg}$ of total protein. The subcellular distribution of the Factor XI-like activity was examined after sucrose density gradient centrifugation (Table II). Of the total protein in the lysate, $93 \%$ was recovered in the soluble fraction, a crude debris fraction (unlysed platelets, mitochondria, and granules), and a plasma membraneenriched microsomal fraction. The debris fraction had $6.5 \mathrm{U}$ and a specific clotting activity of $0.02 \mathrm{U} / \mathrm{mg}$ protein, representing a ratio of 0.4 when compared with the whole lysate fraction. The debris fraction was not studied further. In contrast, the isolated plasma membrane-enriched fraction contained $2.3 \mathrm{U}$ and a specific clotting activity of $0.2 \mathrm{U} / \mathrm{mg}$ of protein, representing a 4.4-fold enrichment in Factor XI-like activity when compared with the lysate. As with washed platelets, the isolated plasma membrane fraction had no detectable Factor II, VII, VIII, IX, or X clotting activity but did have Factor $\mathrm{V}$ activity $(0.4 \mathrm{U} / \mathrm{mg}$ protein) and a
TABLE II

Distribution of Factor XI-like Activity after Glycerol Lysis of Washed Platelets

\begin{tabular}{lcccc}
\hline \multicolumn{1}{c}{ Fraction } & $\begin{array}{c}\text { Total } \\
\text { factor XI }\end{array}$ & $\begin{array}{c}\text { Total } \\
\text { protein }\end{array}$ & $\begin{array}{c}\text { Specific } \\
\text { activity }\end{array}$ & $\begin{array}{c}\text { Ratio to } \\
\text { lysate }\end{array}$ \\
\hline & $U$ & $m g$ & $U / m g$ & \\
$\begin{array}{l}\text { Lysate } \\
\text { Soluble }\end{array}$ & 50 & 1,090 & 0.046 & 1.00 \\
$\begin{array}{l}\text { Debris (unlysed platelets, } \\
\text { mitochondria, granules) }\end{array}$ & 6.5 & 310 & 0.021 & 0.46 \\
Plasma membranes & 2.3 & 11.3 & 0.200 & 4.40 \\
\hline
\end{tabular}

A glycerol lysate of $10 \mathrm{U}\left(6 \times 10^{11}\right.$ platelets $)$ of platelets was subjected to sucrose density gradient centrifugation as described in Methods. The soluble, debris, and plasma membrane-enriched microsomal fractions were assayed for total protein and Factor XI clotting activity. See text for explanation.

trace amount of an unactivated Factor XII clotting activity in addition to Factor XI. Factor XI activity was only found in isolated platelet membranes assayed in the presence of kaolin. This suggests that the Factor XI-like activity occurs in an unactivated state and can participate in the in vitro contact activation steps of intrinsic coagulation.

A possible explanation for the apparent Factor XI activity present in platelet membranes is that they contain phospholipids that shorten clotting times of Factor XI-deficient plasma. The assay mixtures for Factor XI activity in platelet membranes contained 3.25-26 $\mu \mathrm{g}$ of platelet phospholipid in addition to $12.5 \mu \mathrm{g}$ of brain cephalin (Folch extract). The addition of exogenous crude lipid extracts of brain containing more than the usual amount $(12.5 \mu \mathrm{g})$ of phospholipids did not further shorten the clotting times of Factor XI-deficient plasma tested alone or of Factor XI-deficient plasma with varying dilutions of normal plasma added. Moreover, phospholipid amounts $>25 \mu \mathrm{g}$ markedly prolonged clotting times in the Factor XI assay. This result suggests that platelet Factor XI-like activity is not simply a nonspecific phospholipid effect on the Factor XI assay.

The specific activity of some platelet enzymes and Factor XI-like activity was determined in a platelet lysate and in the plasma membrane fraction isolated after sucrose density gradient centrifugation (Table IJI). The isolated membrane fraction was enriched four-fold in Factor XI-like activity when compared with the whole platelet lysate. Similar enrichments were observed in plasma membrane marker enzymes (19) $\mathrm{Na}^{+} \mathrm{K}^{+}$ATPase, phosphodiesterase, alkaline and acid phosphatases, and $\mathrm{Mg}^{2+} \mathrm{Ca}^{2+}$ A TPase. In contrast, membrane:lysate ratios of $<1.0$ were observed for granule $(N$-acetyl- $\beta$-glucosaminidase and $\beta$-glucuronidase), endoplasmic reticulum (esterase), mitochondria (succi- 
TABLE III

Factor XI-like Activity* and Specific Activities $₫$ of Enzymes in a Platelet Lysate and Platelet-Membrane Fraction

\begin{tabular}{|c|c|c|c|}
\hline $\begin{array}{c}\text { Enzyme or } \\
\text { Factor XI activity }\end{array}$ & Lysate & Membrane & $\begin{array}{c}\text { Ratio } \\
\text { membranes/lysate }\end{array}$ \\
\hline & U/mg & U/mg & \\
\hline $\mathrm{Na}^{+} \mathbf{K}^{+}$ATPase & 0.02 & 0.12 & 6.0 \\
\hline Phosphodiesterase & 0.07 & 0.32 & 4.6 \\
\hline Factor XI activity & $0.05^{*}$ & $0.20^{*}$ & 4.0 \\
\hline Alkaline phosphatase & 0.02 & 0.07 & 3.5 \\
\hline Acid phosphatase & 7.5 & 22.0 & 3.0 \\
\hline $\mathrm{Mg}^{2+} \mathrm{Ca}^{2+}$ ATPase & 0.27 & 0.37 & 1.4 \\
\hline$N$-Acetyl- $\beta$-glucosaminidase & 0.59 & 0.50 & 0.85 \\
\hline$\beta$-Glucuronidase & 0.04 & 0.03 & 0.75 \\
\hline Esterase & 1.1 & 0.31 & 0.28 \\
\hline Succinate INT reductase & 0.12 & 0.02 & 0.17 \\
\hline Lactate dehydrogenase & 14.0 & 0.31 & 0.02 \\
\hline
\end{tabular}

INT, iodonitrotetrazolium.

* $1 \mathrm{U}$ is that activity found in $1 \mathrm{ml}$ of pooled normal plasma.

\$ Data are given in micromoles of product formed per hour per milligram protein unless indicated otherwise.

nate iodonitrotetrazolium reductase), and cytosol (lactate dehydrogenase) marker enzymes. The data in Table III are consistent with the view that platelet Factor XI-like activity is predominantly associated with platelet plasma membranes. An exclusive association with plasma membranes, however, has not been demonstrated.

Inhibition by concanavalin A of platelet Factor XIlike activity and plasma Factor XI bound to platelets. The interaction of concanavalin A with whole platelets and isolated plasma membranes has been previously demonstrated (34-37). The effect of concanavalin A on platelet Factor XI-like activity was studied (Fig. 1), and comparisons were made with its effects on plasma Factor XI. Concanavalin A inhibited the Factor XI-like activity of whole platelet lysates and isolated plasma membranes (Fig. 1). Reactions were complete within $6 \mathrm{~min}$ at $37^{\circ} \mathrm{C}$. Agglutination of insoluble membrane material was not observed. Concanavalin A at $25 \mu \mathrm{g} / \mathrm{ml}$ inhibited $50 \%$ of the Factor XI activity in a whole platelet lysate $\left(6.4 \times 10^{8}\right.$ platelets $\left./ \mathrm{ml}\right)$. Inhibition was $90 \%$ or greater at concanavalin A concentrations of 100 and $150 \mu \mathrm{g} / \mathrm{ml}$ (data not shown). Concanavalin A also inhibited the Factor XI-like activity of isolated platelet plasma membrane (Fig. 1). Concanavalin A at $200 \mu \mathrm{g} / \mathrm{ml}$ inhibited $50 \%$ of the Factor XI-like activity in a plasma membrane sample containing $1.4 \mathrm{mg} / \mathrm{ml}$ of membrane protein. In contrast, at concentrations of up to $1 \mathrm{mg} / \mathrm{ml}$, concancavalin A did not inhibit normal plasma Factor $\mathrm{XI}$ clotting activity in experiments with pooled normal plasma or purified plasma Factor XI (data not shown). The inhibition of platelet lysate or isolated plasma membrane Factor XI was reversed by treatment with
$100 \mathrm{mM} \alpha$-methyl-D-mannoside, which had no effect by itself on platelet Factor XI-like activity. This indicates that inhibition of platelet Factor XI-like activity is associated with the interaction between platelets and concanavalin A.

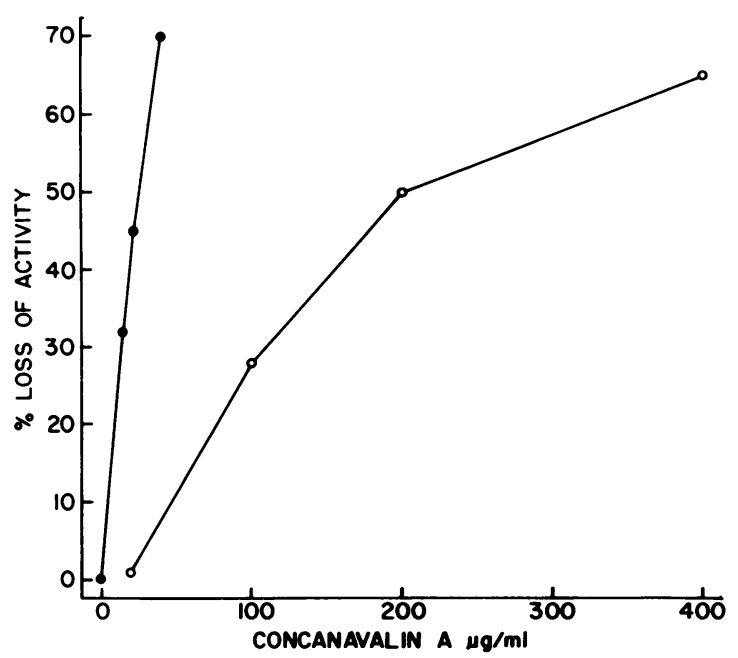

FIGURE 1 Inhibition by concanavalin A of Factor XI activity of platelets and isolated plasma membrane. A platelet suspension $\left(6.4 \times 10^{8}\right.$ platelets $\left./ \mathrm{ml}\right)$ washed by albumin density gradient centrifugation was lysed by freezing and thawing twice. Membranes containing $1.4 \mathrm{mg}$ protein and $0.2 \mathrm{U} / \mathrm{ml}$ Factor XI were prepared according to Methods. Buffered-saline suspensions of lysed platelets $(\Theta)$ or membranes $(O)$ were incubated $10 \mathrm{~min}$ at $37^{\circ} \mathrm{C}$ with concanavalin A. After incubation, samples were diluted to five or six different concentra-

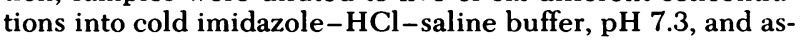
sayed immediately for Factor XI activity. 
When platelet membranes were exposed to purified plasma Factor XI and sedimented by centrifugation, the membranes showed from 10- to 20 -fold increases in Factor XI activity. Of the total purified plasma Factor $\mathrm{XI}, 9 \%$ cosedimented with the membranes; overall recovery of total plasma Factor XI was $47 \%$. Fractions 26 and 27 in Fig. 2 contained 65\% of the total (added) membrane protein and had a specific Factor XI activity of $2.6 \mathrm{U} / \mathrm{mg}$ of membrane protein. In the control experiment omitting plasma membranes, $78 \%$ of the plasma Factor XI was recovered, all at the top of the gradient. The effect of concanavalin A was tested on the free and membrane-bound plasma Factor XI. As depicted in the inset (Fig. 2), concanavalin A inhibited $(50 \%)$ the plasma Factor XI associated with the platelet membrane fraction, whereas unbound plasma Factor XI retained activity in the presence of $1 \mathrm{mg} / \mathrm{ml}$ of

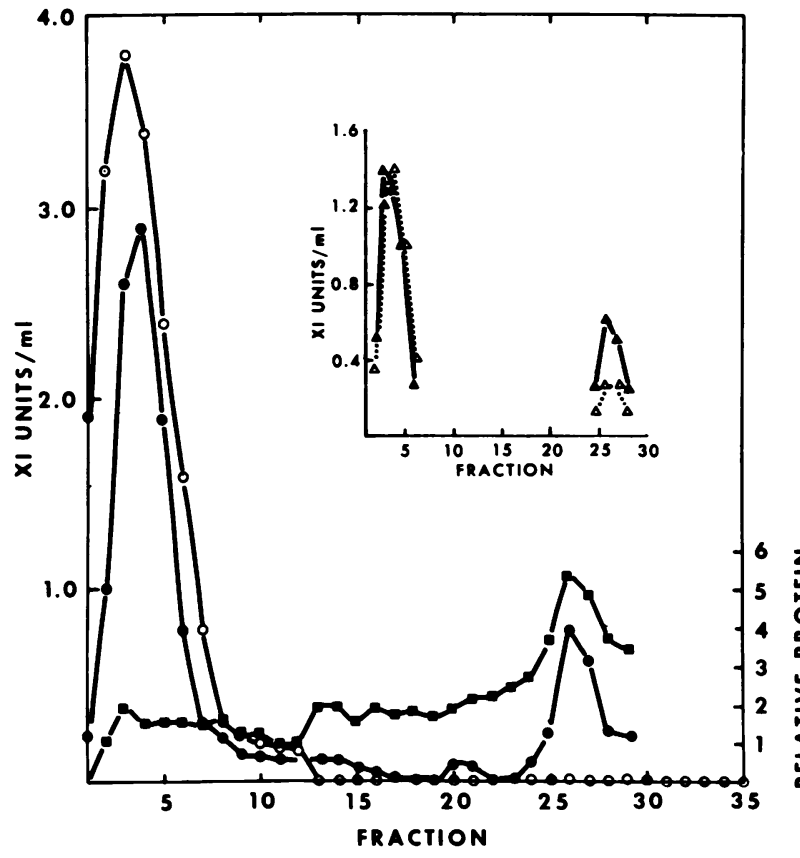

FIGURE 2 Binding of purified plasma Factor XI to platelet plasma membranes. 6 U of purified plasma Factor XI (O) or a mixture of purified plasma Factor XI and platelet plasma membranes (O) (0.2 mg membrane protein) were incubated $1 \mathrm{~h}$ at $0^{\circ} \mathrm{C}$ in a final volume of $0.5 \mathrm{ml}$ containing isotonic salineTris $\mathrm{HCl}, \mathrm{pH}$ 7.3. After incubation, each sample was layered over a discontinuous sucrose gradient formed with $1 \mathrm{ml}$ of $27 \%$ sucrose overlayed with $4 \mathrm{ml}$ of isotonic sucrose-Tris $\mathrm{HCl}, \mathrm{pH}$ 7.5. Each sample was centrifuged at $40,000 \mathrm{~g}$ for $3 \mathrm{~h}$ at $4^{\circ} \mathrm{C}$. Fractions, $0.24 \mathrm{ml}$ each, were serially collected from the top and assayed for Factor XI activity ( $O$ or $\Theta$ ). Fractions designated by were also assayed for membrane protein (ם). Fractions indicated by and $\square$ were taken from the sample to which a mixture of membranes and endogenous plasma Factor XI was added. (Inset) Samples of fractions from the two peaks designated 0 were treated with buffer $(\Delta)$ or $1 \mathrm{mg} / \mathrm{ml}$ (final concentration) concanavalin $\mathbf{A}(\Delta)$, incubated $10 \mathrm{~min}$ at $37^{\circ} \mathrm{C}$, and assayed for Factor XI activity. concanavalin A. Thus, unlike free plasma Factor XI, platelet membrane-bound plasma Factor XI and endogenous platelet Factor XI-like activity are similarly inhibited by concanavalin A.

Failure of collagen to activate plasma Factor XI platelet membrane complex. A complex of plasma Factor XI and platelet plasma membranes was prepared as described above by centrifugation of a suspension containing platelet membranes and purified plasma Factor XI. This complex had 1 U Factor XI clotting activity/mg of membrane protein when assayed with kaolin as described in Methods. The assays were repeated without kaolin in plastic tubes with $10 \mu \mathrm{l}$ of $20 \mu \mathrm{g} / \mathrm{ml}$ collagen in $0.1 \%$ acetic acid or no addition. The measured specific Factor XI activities were 0.06 $\mathrm{U} / \mathrm{mg}$ of protein in the presence and absence of collagen, accounting for only $6 \%$ of the kaolin-activatable Factor XI. Thus, no activation by collagen of membrane-bound plasma Factor XI was observed.

Effect of anti-XI antibody on activities of plasma Factor XI and platelet Factor XI-like activity. Rabbit anti-Factor XI antibody was a potent inhibitor of the clotting activity of highly purified plasma Factor XI and trypsin-activated Factor XI (Factor $\mathrm{XI}_{\mathrm{a}}$ ) (see Methods). Anti-Factor XI antibody had no appreciable effect on the Factor XI-like activity of lysed platelets or isolated plasma membranes. A platelet lysate containing $6.5 \times 10^{8}$ platelets $/ \mathrm{ml}$ had $3 \mathrm{U}$ of Factor XI-like clotting activity after a 5 -min incubation at $37^{\circ} \mathrm{C}$ with 0.05 vol of $0.9 \%$ saline, rabbit preimmune antibody, or rabbit anti-Factor XI antibody. An isolated platelet plasma membrane fraction containing $0.1 \mathrm{U}$ Factor XIlike activity/mg of membrane protein retained full activity after incubation for $5 \mathrm{~min}$ at $37^{\circ} \mathrm{C}$ with $0.05 \mathrm{vol}$ rabbit anti-Factor XI antibody. Thus, the endogenous Factor XI-like activity of platelet lysates and isolated platelet membranes was not neutralized by anti-Factor XI antibody.

To determine whether plasma Factor XI retains available antigenic sites when bound to platelet membranes, $0.7 \mathrm{ml}$ of a platelet plasma membrane fraction (0.14 Factor XI-like U/ml) was incubated with $0.1 \mathrm{ml}$ of purified plasma Factor XI $(130 \mathrm{U} / \mathrm{ml})$ or buffer in a final volume of $1.0 \mathrm{ml}$ buffered $0.9 \%$ saline, $\mathrm{pH} 7.1-7.3$, for $1 \mathrm{~h}$ at $0-4^{\circ} \mathrm{C}$. The suspension was diluted with up to

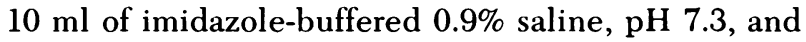
the membranes collected by centrifugation for $1 \mathrm{~h}$ at $100,000 \mathrm{~g}$. The supernate was discarded, and the tube wall and membrane pellet were washed once with 1.0 $\mathrm{ml}$ of suspension buffer which was discarded. The membrane pellet was resuspended in $1.0 \mathrm{ml}$ of imidazole-buffered $0.9 \%$ saline, $\mathrm{pH} 7.3$, and treated with 0.05 vol rabbit preimmune serum or rabbit anti-Factor XI antibody for $5 \mathrm{~min}$ at $37^{\circ} \mathrm{C}$. The results are summarized in Table IV. In suspended samples incubated with plasma Factor XI, the recovered Factor XI activity 
TABLE IV

Inhibition of Membrane-Bound Plasma Factor XI by Anti-XI Antibody

\begin{tabular}{lcccc}
\hline & \multicolumn{5}{c}{ Test } \\
\cline { 2 - 5 } \multicolumn{1}{c}{ Addition } & 1 & 2 & 3 & 4 \\
\hline Platelet membranes, $0.7 \mathrm{ml}$ & + & + & + & + \\
Purified Factor XI & + & + & - & - \\
Rabbit preimmune antibody & + & - & + & - \\
Rabbit anti-Factor XI antibody & - & + & - & + \\
Recovered Factor XI activity, $U$ & 1 & 0.09 & 0.05 & 0.05 \\
\hline
\end{tabular}

Details are described in the text. Additions are listed in lines $1-4$ and results are recorded in line 5 .

was $1 \mathrm{U}$ or $0.09 \mathrm{U} / \mathrm{ml}$, respectively, for samples treated with rabbit preimmune antibody or anti-Factor XI antibody. The $0.09 \mathrm{U} / \mathrm{ml}$ in antibody-treated samples could be accounted for by the endogenous Factor XI-like activity. Alternatively, it could represent endogenous Factor XI-like activity $(0.05 \mathrm{U} / \mathrm{ml})$ plus a small fraction of purified Factor XI not inhibited by antibody (0.04 $\mathrm{U} / \mathrm{ml}$ ). In each suspended sample incubated without plasma Factor XI, the recovered Factor XI-like endogenous activity was $0.05 \mathrm{U} / \mathrm{ml}$ regardless of treatment with rabbit preimmune or anti-Factor XI antibody. This result indicates that the majority (at least $90 \%$ ) of antigenic sites on plasma Factor XI are retained when it is bound to platelet membranes. Consequently, unlike the endogenous platelet Factor XI-like activity, membrane-bound plasma Factor XI activity was virtually abolished by rabbit anti-Factor XI antibody at the same time that complete recovery of the platelet membrane endogenous Factor XI-like activity was observed.

Factor XI-like activity of washed platelets and platelet plasma membranes from a Factor XI-deficient patient without a history of bleeding. Plasma was obtained from a Factor XI-deficient patient without a history of excessive bleeding. The plasma gave clotting times no different from the blank in an assay for Factor $\mathrm{XI}$ and a kaolin-activated partial thromboplastin time of about 5 min compared with about $1 \mathrm{~min}$ for a pool of normal control plasma. The patient's partial thromboplastin time was specifically corrected to normal by purified Factor XI. The plasma gave normal clotting times in assays for Factors II, VII, IX, X, VIII, and XII. When platelets obtained from this patient were washed by albumin density gradient centrifugation and tested for collagen-induced coagulant activity $(1,33)$, the results were entirely normal. As it was previously proposed that the normal development of collagen-induced coagulant activity depends on platelet Factor XI activity (1), we compared Factor XI-like activity associated with platelets and isolated plasma membranes from five normal donors and from this patient with plasma Factor XI deficiency and no hemostatic defect. The results are shown in Fig. 3. Platelets from five normal donors or the patient were tested without prior treatment, after treatment with acid-soluble collagen, or after freezing and thawing. The amount of Factor XI-like activity per $10^{11}$ platelets obtained from the patient was essentially equivalent to the normal results. Similarly, the patient's platelet membranes contained $0.27 \mathrm{U}$ Factor XI-like activity/mg protein, very near the value of $0.23 \mathrm{U} / \mathrm{mg}$ for normals.

\section{DISCUSSION}

The experiments reported here confirm previous observations (6) that the coagulant activities of Factors II, VII, VIII, IX, X, and XII can be eluted from platelets. In contrast, the coagulant activities of Factors $V$ and XI are retained (6) and increase upon platelet lysis or treatment with collagen. Factor $\mathrm{V}$ antigen has been demonstrated in platelets (38) in an anticipated form (39), and it has been postulated that platelet Factor $\mathrm{V}$ is the "receptor" for Factor $\mathrm{X}_{\mathrm{a}}(40)$. The Factor XI-like activity of platelets $(1,6,41-44)$ is shown here to differ from platelet Factor $\mathrm{V}$ in several respects. When platelet lysates were examined after ultracentrifugation, almost all the Factor XI activity was found in the particulate fraction, whereas $38 \%$ of the Factor $\mathrm{V}$ activity was soluble. This observation is consistent with evidence that Factor $\mathrm{V}$ is stored in platelet granules and released in soluble form by collagen (45). Furthermore,

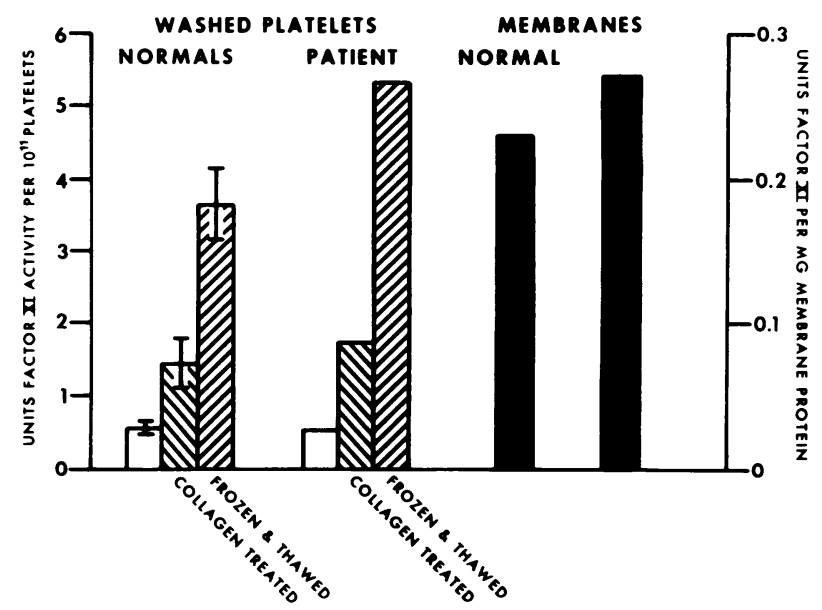

FIGURE 3 Factor XI activity of washed platelets and platelet membranes from five normal donors and a patient with plasma Factor XI deficiency without bleeding. Details are described in the text. The height of the bars represents results of Factor XI activity expressed as units per $10^{11}$ platelets for washed platelets (left side of figure) and as units per milligrams protein for platelet membranes (right side of figure). The brackets represent mean $\pm S E M$. 
when platelet lysates were solubilized by treatment with the detergent Triton X-100, most (70\%) of the Factor $\mathrm{V}$ activity was solubilized, whereas the Factor XI activity was not detected. These observations are consistent with those of others that Factor $\mathrm{V}$ can bind to disrupted or activated platelet membranes $(39,45)$ and suggest that the Factor XI-like activity depends at least in part on the presence of intact platelet membranes.

The evidence presented here indicates that the Factor XI-like activity is localized in platelet plasma membranes. First, almost all (93\%) of the Factor XI-like activity of a platelet lysate was associated with the particulate fraction. Second, when a glycerol lysate of washed platelets was examined by sucrose density gradient centrifugation, a 4.4-fold enrichment of Factor XIlike activity was observed in the plasma membraneenriched microsomal fraction compared with the lysate, whereas the soluble fraction and the debris (containing unlysed platelets, mitochondria, and granules) were relatively poor in Factor XI-like activity (Table II). Third, when a platelet lysate and a plasma membrane fraction were examined for the specific activities of various cellular enzymes and for Factor XI-like activity, the membrane fraction was found to be similarly enriched in plasma membrane marker enzymes and in Factor XI-like activity (Table III). Therefore, it is concluded that the Factor XI-like activity is specifically, although not necessarily exclusively, localized in platelet plasma membranes.

The demonstration that the platelet Factor XI-like activity is localized in plasma membranes, which are capable of binding purified plasma Factor XI, suggests the possibility that the endogenous platelet Factor XIlike activity arises from membrane binding of exogenous plasma Factor XI. Our studies with concanavalin A, which inhibited both endogenous platelet Factor XIlike and membrane-bound plasma Factor XI activities but not purified Factor XI, are consistent with this possibility. However, an antibody prepared in rabbits against purified human Factor XI was capable of specifically inhibiting plasma Factor XI but had no effect on the Factor XI-like activity of either lysed platelets or platelet membranes. That purified Factor XI bound to platelet membranes retained antigenic sites recognized by the antibody was demonstrated in an experiment (Table IV) in which bound plasma Factor XI activity was inhibited by the antibody. Thereby, the endogenous Factor XI-activity of platelet membranes is functionally distinguished from plasma Factor XI. It seems most likely that the platelet Factor XI-like activity arises from a molecule similar or identical to plasma Factor XI situated in the plasma membrane, so as to protect it from inhibition by anti-Factor XI antibody.
Washed platelets and platelet membranes obtained from a patient with no detectable plasma Factor XI contained normal amounts of Factor XI-like activity (Fig. 3). This suggests but does not prove that the platelet Factor XI-like activity is not of plasma origin. The fact that this patient had no history of abnormal bleeding and her platelets responded normally to collagen in an assay for collagen-induced coagulant activity suggests that the Factor XI-like activity of platelets has a role in the maintenance of normal hemostasis even in the absence of plasma Factor XI. These results are in agreement with those of Connellan et al. (44) who found that platelets obtained from a Factor XI-deficient patient contained Factor XI-like activity that was increased by collagen treatment or lysis and that the Factor XI-like activity of normal platelets resided in the membrane fraction after glycerol lysis. The suggestion that platelet Factor XI-like activity has an important role in maintaining normal hemostasis is supported by our studies of two patients with clinically important bleeding caused by the hereditary giant platelet (Bernard-Soulier) syndrome whose platelets lacked Factor XI-like activity, failed to respond to collagen in the assay for collagen-induced coagulant activity, and were deficient in their capacity to promote prothrombin consumption (46).

\section{ACKNOWLEDGMENTS}

The technical assistance of Mr. Robert Farmer is gratefully acknowledged.

These studies were supported in part by a grant (HL14217) from the National Institutes of Health and a grant (73-726) from the American Heart Institute.

\section{REFERENCES}

1. Walsh, P. N. 1972. The effects of collagen and kaolin on the intrinsic coagulant activity of platelets. Evidence for an alternative pathway in intrinsic coagulation not requiring factor XII. Br. J. Haematol. 22: 393-405.

2. Niewiarowski, S. E., Bańkowski, and I. Rogowicka. 1965. Studies on the adsorption and activation of the Hageman factor (factor XII) by collagen and elastin. Thromb. Diath. Haemorrh. 14: 387-400.

3. Wilner, G. D., H. L. Nossel, and E. C. LeRoy. 1968. Activation of Hageman factor by collagen. J. Clin. Invest. 47: 2608-2615.

4. Milstone, J. H. 1964. Thrombokinase as a prime activator of prothrombin: historical perspectives and present status. Fed. Proc. 23: 742-748.

5. Marcus, A. J., D. Zucker-Franklin, L. B. Safier, and H. L. Ullman. 1966. Studies on human platelet granules and membranes. J. Clin. Invest. 45: 14-27.

6. Walsh, P. N. 1972. Albumin density gradient separation and washing of platelets and the study of platelet coagulant activities. Br. J. Haematol. 22: 205-217.

7. Fiske, C. H., and Y. Subbarow. 1925. The colorimetric determination of phosphorus. J. Biol. Chem. 66: 375-400.

8. Day, H. J., and H. Holmsen. 1972. Laboratory tests of platelet function. Ann. Clin. Lab. Sci. 2: 63-74.

9. Biggs, R. 1972. Human Blood Coagulation, Haemostasis, 
and Thrombosis. Blackwell Scientific Publications Ltd., Oxford. 596-597.

10. Walsh, P. N., D. C. B. Mills, and J. G. White. 1977. Metabolism and function of human platelets washed by albumin density gradient separation. Br.J. Haematol. 36: 281-296.

11. Brecher, G., and E. P. Cronkite. 1950. Morphology and enumeration of human blood platelets. J. Appl. Physiol. 3: 365-377.

12. Lowry, O. H., N. J. Rosebrough, A. L. Farr, and R. J. Randall. 1951. Protein measurement with the Folin phenol reagent. J. Biol. Chem. 193: 265-275.

13. Ouchterlony, O. 1949. Antigen-antibody reactions in gels. Acta Pathol. Microbiol. Scand. 26: 507-515.

14. Porath, J. 1974. General methods and coupling procedures. Methods Enzymol. 34(part B): 13-30.

15. Cuatrecasas, P. 1970. Protein purification by affinity chromatography. J. Biol. Chem. 245: 3059-3065.

16. Fujikawa, K., A. R. Thompson, M. E. Legaz, R. G. Meyer, and E. W. Davie. 1973. Isolation and characterization of bovine factor IX (Christmas factor). Biochemistry. 12: 4938-4945.

17. Wilchek, M., V. Bocchini, M. Becker, and D. Givol. 1971. A general method for the specific isolation of peptides containing modified residues, using insoluble antibody columns. Biochemistry. 10: 2828-2834.

18. Baenziger, N. L., and P. W. Majerus. 1974. Isolation of human platelets and platelet surface membranes. Methods Enzymol. 31(part A): 149-155.

19. Barber, A. J., and G. A. Jamieson. 1970. Isolation and characterization of plasma membranes from human blood platelets. J. Biol. Chem. 245: 6357-6365.

20. Bosmann, H. B., A. Hagopian, and E. H. Eylar. 1968. Cellular membranes: the isolation and characterization of the plasma and smooth membrane of HeLa cells. Arch. Biochem. Biophys. 128: 51-69.

21. Folch, J., M. Lees, and G. H. Sloane-Stanley. 1957. A simple method for the isolation and purification of total lipids from animal tissues. J. Biol. Chem. 226: 497-509.

22. Böttcher, C. J. F., C. M. van Gent, and C. Pries. 1961. $A$ rapid and sensitive sub-micro phosphorus determination. Anal. Chim. Acta. 24: 203-204.

23. Bartlett, G. R. 1959. Phosphorus assay in column chromatography. J. Biol. Chem. 234: 466-468.

24. Walsh, P. N., and M. S. Lipscomb. 1976. Comparison of the coagulant activities of platelets and phospholipids. Br. J. Haematol. 33: 9-18.

25. Chambers, D. A., E. W. Salzman, and L. L. Neri. 1967. Characterization of "ecto-ATPase" of human blood platelets. Arch. Biochem. Biophys. 119: 173-178.

26. Wallach, D. F. H., and V. B. Kamat. 1966. Preparation of plasma-membrane fragments from mouse ascites tumor cells. Methods Enzymol. 8: 164-172.

27. Koerner, J. F., and R. L. Sinsheimer. 1957. A deoxyribonuclease from calf spleen. I. Purification and properties. J. Biol. Chem. 228: 1039-1048.

28. Linhardt, K., and K. Walter. 1963. Phosphatases (phosphomonoesterases). In Methods of Enzymatic Analysis. H. U. Bergmeyer, editor. Academic Press Inc., New York. 779-784.
29. Langley, J. J., and F. R. Jevons. 1968. Characterization of beef-liver glycosidases possibly involved in glycoprotein degradation. Arch. Biochem. Biophys. 128: 312-318.

30. Talalay, P., W. H. Fishman, and C. Huggins. 1946. Chromogenic substrates. III. Phenolphthalein glucuronic acid as substrate for the assay of glucuronidase activity. J. Biol. Chem. 166: 757-772.

31. Bier, M. 1955. Lipases. Methods Enzymol. 1: 627-642.

32. Pennington, R. J. 1961. Biochemistry of dystrophic muscle. Mitochondrial succinate-tetrazolium reductase and adenosine triphosphatase. Biochem. J. 80: 649-654.

33. Walsh, P. N. 1972. Platelet coagulant activities in thrombasthenia. Br. J. Haematol. 23: 553-569.

34. Majerus, P. W., and G. N. Brodie. 1972. The binding of phytohemagglutinins to human platelet plasma membranes. J. Biol. Chem. 247: 4253-4257.

35. Nachman, R. L., A. Hubbard, and B. Ferris. 1973. Iodination of the human platelet membrane. Studies of the major surface glycoproteins. J. Biol. Chem. 248: 2928-2936.

36. Schmukler, M., and P. D. Zieve. 1974. The effect of concanavalin A on human platelets and their response to thrombin. J. Lab. Clin. Med. 83: 887-894.

37. Patscheke, H., and R. Brossmer. 1975. Concanavalin Ainduced aggregation of human blood platelets. Thromb. Diath. Haemorrh. 33: 354-360.

38. Breederveld, K., J. C. Giddings, J. W. ten Cate, and A. L. Bloom. 1975. The localization of factor $\mathrm{V}$ within normal human platelets and the demonstration of a plateletfactor $\mathrm{V}$ antigen in congenital factor $\mathrm{V}$ deficiency. $\mathrm{Br}$. J. Haematol. 29: 405-412.

39. $\emptyset$ sterud, B., S. I. Rapaport, and K. K. Lavine. 1977. Factor $\mathrm{V}$ activity of platelets. Evidence for an activated factor $\mathrm{V}$ molecule and for a platelet activator. Blood. 49: 819-834.

40. Miletich, J. P., D. W. Majerus, and P. W. Majerus. 1978. Patients with congenital Factor V deficiency have decreased Factor $\mathrm{X}_{\mathrm{a}}$ binding sites on their platelets. J. Clin. Invest. 62: 824-831.

41. Horowitz, H. I., and M. M. Fujimoto. 1965. Association of factors XI and XII with blood platelets. Proc. Soc. Exp. Biol. Med. 119: 487-492.

42. Schiffman, S., S. I. Rapaport, and M. M. Y. Chong. 1973. Platelets and initiation of intrinsic clotting. Br. J. Haematol. 24: 633-642.

43. Schiffman, S., A. Rimon, and S. I. Rapaport. 1977. Factor XI and platelets: evidence that platelets contain only minimal factor XI activity and antigen. $\mathrm{Br}$. J. Haematol. 35: 429-436.

44. Connellan, J. M., P. A. Castaldi, and R. H. Muntz. 1977. The role of factor XI in the coagulant activity of platelets. Haemostasis. 6: 41-52.

45. Pifer, D. D., R. W. Colman, and C. McI. Chesney. 1977. Subcellular localization and secretion of factor $\mathrm{V}$ by human platelets. Thromb. Haemostasis. 38: 126. (Abstr.)

46. Walsh, P. N., D. C. B. Mills, F. I. Pareti, G. J. Stewart, D. E. Macfarlane, M. E. Johnson, and J. J. Egan. 1975. Hereditary giant platelet syndrome. Absence of collageninduced coagulant activity and deficiency of factor-XI binding to platelets. Br. J. Haematol. 29: 639-655. 